\title{
CYTOTOXIC AND ANTIGEN PRESENTING CELLS, AND NON-BASEMENT MEMBRANE ZONE PATHOLOGY IN A CASE OF BULLOUS PEMPHIGOID
}

\author{
by Ana Maria Abreu Velez, Vickie M. Brown, Michael S. Howard
}

comment:

Dr Sho Hiroyasu, Daisuke Tsuruta, MD PhD

As the most common autoimmune blistering disease, many dermatologists have made efforts to elucidate the mechanism of bullous pemphigoid (BP) to date. One of their most important findings is that the target antigens of BP autoantibodies are two protein components of the hemidesmosome, a $180-\mathrm{kDa}$ transmembrane protein member of the collagen family (BP180/type XVII collagen/BPAG2) and a $230-\mathrm{kDa}$ protein member of the plakin cytoskeleton linker family (BP230/BPAG1e) [1-4]. Although anti-BP230 autoantibodies in BP patients directly contribute to BP pathogenesis is a matter of controversy [5-6], several studies suggested that $\operatorname{IgG}$ autoantibodies against BP180 contribute to blister formation in BP [7-8]. Using the experimental animal models, Liu et al. showed that blister formation depends on complement activation, mast cell degranulation and neutrophil infiltration [9-11]. However, contrary to this conclusion, recent studies indicate that cultured keratinocytes treated with BP-IgG exhibit a reduction in adhesive strength and a loss in expression of BP180 [12]. Furthermore, recently, many groups pay attention to the association between BP and IgE autoantibodies against BP180 [13-15]. Most of above researches focused on the mechanism of blister and erythema formation in BP. In addition, some recent papers showed that cardiovascular and neurological diseases are associated with BP [16-19]. However, the contribution of these complications on the pathogenesis of BP is still absolutely unclear. Now Velez et al. convincingly showed autoantibody deposition and inflammation on dermal eccrine sweat glands, blood vessels and nerve, which may give us a hint of the mechanism which can cause cardiovascular and neurological diseases. Further studies are required.

\section{REFERENCES}

1. Labib RS, Anhalt GJ, Patel HP, Mutasim DF, Diaz LA: Molecular heterogeneity of the bullous pemphigoid antigens as detected by immunoblotting. J Immunol. 1986; 136: 1231-1235.
2. Diaz LA, Ratrie H 3rd, Saunders WS, Futamura S, Squiquera HL, Anhalt GJ, et al.: Isolation of a human epidermal cDNA corresponding to the $180-\mathrm{kD}$ autoantigen recognized by bullous pemphigoid and herpes gestationis sera. Immunolocalization of this protein to the hemidesmosome. J Clin Invest. 1990; 86: 1088-1094.

3. Stanley JR, Hawley-Nelson P, Yuspa SH, Shevach EM, Katz SI: Characterization of bullous pemphigoid antigen: a unique basement membrane protein of stratified squamous epithelia. Cell. 1981; 24: 897-903.

4. Stanley JR, Tanaka T, Mueller S, Klaus-Kovtun V, Roop D: Isolation of complementary DNA for bullous pemphigoid antigen by use of patients' autoantibodies. J Clin Invest. 1988; 82: 1864-1870.

5. Hall RP 3rd, Murray JC, McCord MM, Rico MJ, Streilein RD: Rabbits immunized with a peptide encoded for by the $230-\mathrm{kD}$ bullous pemphigoid antigen cDNA develop an enhanced inflammatory response to UVB irradiation: a potential animal model for bullous pemphigoid. J Invest Dermatol. 1993; 101: 9-14.

6. Kiss M, Husz S, Janossy T, Marczinovits I, Molnar J, Korom I, et al.: Experimental bullous pemphigoid generated in mice with an antigenic epitope of the human hemidesmosomal protein BP230. J Autoimmun. 2005; 24: 1-10.

7. Liu Z, Diaz LA, Troy JL, Taylor AF, Emery DJ, Fairley JA, et al.: A passive transfer model of the organ-specific autoimmune disease, bullous pemphigoid, using antibodies generated against the hemidesmosomal antigen, BP180. J Clin Invest. 1993; 92: 2480-2488.

8. Nishie W, Sawamura D, Goto M, Ito K, Shibaki A, McMillan JR, et al.: Humanization of autoantigen. Nat Med. 2007; 13: 378-383.

9. Liu Z, Giudice GJ, Swartz SJ, Fairley JA, Till GO, Troy JL, et al.: The role of complement in experimental bullous pemphigoid. J Clin Invest. 1995; 95: 1539-1544.

10. Liu Z, Giudice GJ, Zhou X, Swartz SJ, Troy JL, Fairley JA, et al.: A major role for neutrophils in experimental bullous pemphigoid. J Clin Invest. 1997; 100: 1256-1263. 
11. Chen R, Ning G, Zhao ML, Fleming MG, Diaz LA, Werb $Z$, et al.: Mast cells play a key role in neutrophil recruitment in experimental bullous pemphigoid. J Clin Invest. 2001; 108: 1151-1158.

12. Iwata H, Kamio N, Aoyama Y, Yamamoto Y, Hirako Y, Owaribe $\mathrm{K}$, et al.: IgG from patients with bullous pemphigoid depletes cultured keratinocytes of the $180-\mathrm{kDa}$ bullous pemphigoid antigen (type XVII collagen) and weakens cell attachment. J Invest Dermatol. 2009; 129: 919-926.

13. Zone JJ, Taylor T, Hull C, Schmidt L, Meyer L: IgE basement membrane zone antibodies induce eosinophil infiltration and histological blisters in engrafted human skin on SCID mice. J Invest Dermatol. 2007; 127: 1167-1174.

14. Fairley JA, Burnett CT, Fu CL, Larson DL, Fleming $\mathrm{MG}$, Giudice GJ: A pathogenic role for IgE in autoimmunity: bullous pemphigoid IgE reproduces the early phase of lesion development in human skin grafted to nu/nu mice. J Invest Dermatol. 2007; 127: 2605-2611.

15. Fairley JA, Baum CL, Brandt DS, Messingham KA: Pathogenicity of IgE in autoimmunity: successful treatment of bullous pemphigoid with omalizumab. J Allergy Clin Immunol. 2009; 123: 704-705.

16. Chen YJ, Wu CY, Lin MW, Chen TJ, Liao KK, Chen YC, et al.: Comorbidity profiles among patients with bullous pemphigoid: a nationwide population-based study. $\mathrm{Br} \mathrm{J}$ Dermatol. 2011; 165: 593-599.
17. Langan SM, Groves RW, West J: The relationship between neurological disease and bullous pemphigoid: a population-based case-control study. J Invest Dermatol. 2011; 131: 631-636.

18. Taghipour K, Chi CC, Vincent A, Groves RW, Venning V, Wojnarowska F: The association of bullous pemphigoid with cerebrovascular disease and dementia: a case-control study. Arch Dermatol. 2010; 146: 1251-1254.

19.Tsuruta DNT, Yamagami J, Hashimoto T: Unilateral bullous pemphigoid without erythema and eosinophil infiltration in a hemiplegic patient. Journal of Dermatology. 2012 ; in press.

\section{Correspondence:}

Dr. Daisuke Tsuruta, PhD

Department of Dermatology, Osaka City University Graduate School of Medicine, 1-4-3 Asahimachi, Abeno-ku, Osaka 545-8585 Japan

Tel. +81666453826

Fax +81666453828

E-mai:m0029232@med.osaka-cu.ac.jp 